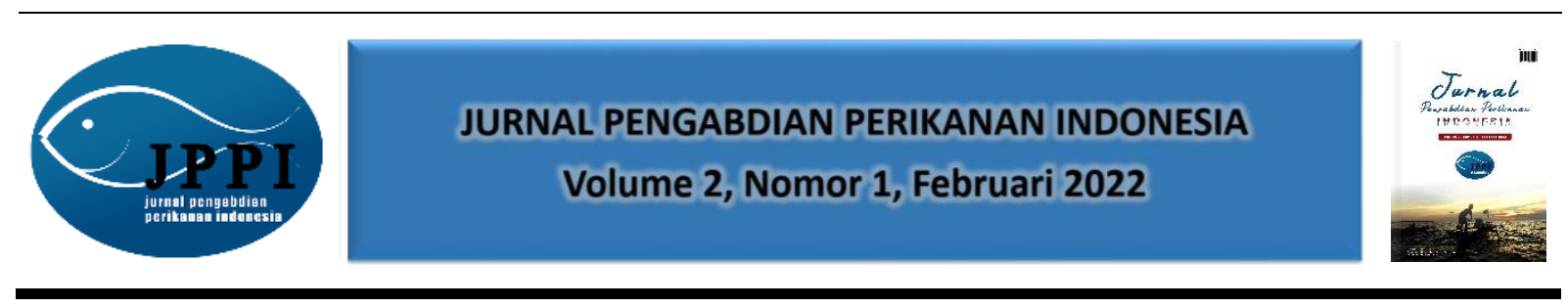

\title{
PENGOLAHAN LIMBAH UDANG VANNAME DALAM RANGKA PENINGKATAN KETAHANAN PANGAN MASYARAKAT PADA MASA PANDEMI COVID19 DI DESA PEMENANG, LOMBOK UTARA
}

\author{
Baiq Hilda Astriana ${ }^{1 *}$, Ayu Adhita Damayanti ${ }^{1}$, Chandrika Eka Larasati ${ }^{1}$, Paryono ${ }^{1}$, Mahardika Rizki \\ Himawan ${ }^{1}$, Dewi Putri Lestari ${ }^{2}$
}

${ }^{1}$ Program Studi Ilmu Kelautam, Fakultas Pertanian, Universitas Mataram, ${ }^{2}$ Program Studi Budidaya Perairan, Fakultas Pertanian, Universitas Mataram

Jalan Pendidikan No. 37, Mataram 83126

*)alamat korespondensi: hilda.baiq@unram.ac.id

Keyword: Abstrak:

limbah Manfaat limbah udang berupa cangkang dan kepala udang belum banyak diketahui udang, oleh masyarakat. Hasil analisis tepung dari limbah ini memiliki kandungan protein pengolahan, sebesar $63 \%$. Apabila bahan ini ditambahkan ke makanan sehari-hari maka dapat kaldu, Desa meningkatkan nilai gizi makanan tersebut. Dengan adanya bencana alam yaitu gempa Pemenang di tahun 2018 yang diikuti oleh pandemi COVID19, lumpuhnya sektor wisata menyebabkan menurunnya pendapatan masyarakat di desa Pemenang. Masalah lain yang muncul adalah meningkatnya lokus stunting atau gagal tumbuh akibat kekurangan gizi kronis di daerah ini. Kegiatan ini bertujuan untuk memberikan pelatihan pengolahan cangkang dan kepala udang menjadi bubuk kaldu udang sebagai zat aditif alami yang memiliki nilai gizi. Selain itu, diversifikasi pemanfaatan kaldu bubuk udang ini diharapkan dapat meningkatkan added value dari panganan lokal. Metode pendekatan yang diterapkan dalam kegiatan pengabdian ini adalah metode penyelesaian masalah yang meliputi penyuluhan serta pelatihan yang dibarengi dengan inisiasi pembentukan dan pendampingan kelompok masyarakat termasuk pemberian bantuan peralatan. Hasil dari kegiatan pengabdian ini adalah meningkatnya pengetahuan peserta kegiatan mengenai manfaat limbah udang, dan diperolehnya keterampilan mengolah limbah udang menjadi bahan makanan yang memiliki nilai gizi dan ekonomi. Selain itu, sebagai tindak lanjut dari kegiatan ini, sampel kaldu bubuk udang yang dihasilkan dianalisa di laboratorium untuk mengetahui kandungan nutrisi yang dimiliki.

Panduan Sitasi (APPA $7^{\text {th }}$ edition) :

Astriana, B. H., Damayanti, A. A., Larasati, C. E., Paryono, Himawan, M. R., \& Lestari, D. P. (2022). Pengolahan Limbah Udang Vanname Dalam Rangka Peningkatan Ketahanan Pangan Masyarakat Pada Masa Pandemi Covid19 Di Desa Pemenang, Lombok Utara. Jurnal Pengabdian Perikanan Indonesia, 2(1), 12-19. https://doi.org/10.29303/jppi.v2i1.503. 


\section{PENDAHULUAN}

Sektor pariwisata di Provinsi Nusa Tenggara Barat merupakan salah satu sektor penggerak perekonomian masyarakat. Salah satu yang terkenal di daerah ini adalah Gili Matra (Meno, Air, dan Trawangan). Pariwisata yang berkembang di kawasan Gili Matra telah menyumbangkan 40-45\% PAD untuk Kabupaten Lombok Utara (KLU) (Nursyamsyi, 2018). Melihat angka ini, dapat diketahui bahwa sektor wisata 3 Gili ini sangat diandalkan oleh masyarakat setempat.

Desa Pemenang adalah desa di KLU yang lokasinya berhadapan langsung dengan Gili Matra dan sebagian besar pekerja di sektor pariwisata ini berasal dari Desa tersebut. Lumpuhnya sektor pariwisata akibat bencana alam (gempa bumi di tahun 2018) yang diikuti munculnya pandemi COVID19 secara langsung berakibat buruk terhadap perekonomian masyarakat setempat. Tentu saja hal ini memperbesar tantangan dalam upaya pencapaian ketahanan pangan.

Sebagai salah satu upaya megurangi kemiskinan di KLU, pemerintah setempat di bawah koordinasi Dinas Perhubungan Kelautan dan Perikanan dengan DPRD dan DPD RI, kini mulai mengembangkan kegiatan lain di sektor kelautan dan perikanan yaitu budidaya udang vanname. Kegiatan ini memang diprioritaskan bagi keluarga miskin (Farida, 2020). Peningkatan unit budidaya ke depannya diprediksi akan meningkatkan jumlah produksi udang vanname di KLU.

Udang vanname sebagaimana diketahui merupakan salah satu komoditas perikanan yang sangat diminati karena memiliki rasa yang enak, aroma yang menarik, serta nilai gizi yang tinggi. Pengolahan udang menjadi makanan seringkali menyisakan limbah berupa cangkang dan kulit udang. Tidak hanya pada kegiatan industri pengolahan udang, proses pengolahan skala rumah tangga juga seringkali menghasilkan limbah tersebut.

Manfaat limbah kepala dan cangkang udang sudah banyak diteliti, akan tetapi pengolahan limbah ini untuk dijadikan bahan makanan belum banyak dilakukan. Limbah udah diketahui mengandung protein kasar 25-40\%, kalsium karbonat 45-50\% dan kitin 15-20\% (Muzzarelli \& Joles, 2000 dalam Wowor et al, 2015). Selain itu, limbah ini juga mengandung karotenoid yang menjadi sumber pro Vitamin A yang bermanfaat untuk pembentukan warna kulit (Muzzarelli \& Joles, 2000 dalam Wowor et al, 2015). Pigmen ini juga memiliki kemampuan menangkal radikal bebas 500 kali lebih baik daripada antioksidan vitamin E (Hu et al., 2019 dalam Atika dan Handayani 2019).

Ditinjau dari aspek rasa dan tekstur, penambahan hasil olahan limbah cangkang dan kepala udang dapat dikatakan baik. Beberapa penelitian yang pernah dilakukan menunjukkan bahwa penambahan $75 \%$ kaldu kepala udang sebagai penambah rasa pada kerupuk ikan lele memberikan hasil yang berpengaruh nyata terhadap warna, aroma, daya kembang, dan rasa (Akbar et al., 2017). Selain itu, penelitian yang dilakukan Atika dan Handayani (2019) mengenai analisa sensoris terhadap sampel kaldu kepala dan cangkang udang dengan persentase penambahan 52,63\% menunjukkan bahwa $90 \%$ panelis menyukai rasa dari kaldu tersebut.

Berdasarkan uraian di atas, diperlukan adanya suatu pendekatan seperti perluasan spektrum pangan atau inovasi dalam diversifikasi berbasis bahan pangan lokal dalam rangka mendukung pencapaian ketahanan pangan masyarakat. Hal inilah yang mendorong untuk dilakukannya kegiatan pengabdian pada masyarakat yaitu Pengolahan Kepala dan Kulit Udang Vanname untuk Mendukung Ketahanan Pangan Masyarakat pada Masa Pandemi COVID-19 di Desa Pemenang, Lombok Utara.

\section{METODE KEGIATAN}

Metode yang digunakan dalam kegiatan ini adalah metode penyelesaian masalah yaitu dengan cara pemberian pelatihan pembuatan bubuk kaldu dari limbah kulit dan kepala udang. 
Sebagai upaya penyelesaian masalah, maka dibuatlah kerangka pemecahan masalah yaitu:

1. Menyediakan tim pelatih yang memiliki kompetensi/terampil dalam mengolah limbah udang

2. Persiapan kegiatan dilakukan secara menyeluruh meliputi persiapan peralatan dan bahan yang dibutuhkan dalam kegiatan, maupun perizinan dengan berkoordinasi dengan pemerintah desa setempat

3. Pelaksanaan evaluasi di akhir kegiatan dengan melakukan interview dengan peserta kegiatan

4. Metode pelatihan yang digunakan yaitu dengan memberikan ceramah, tanya jawab, dan demonstrasi.

Sasaran kegiatan ini adalah kelompok ibu-ibu pembuat panganan lokal yang ada di Desa Pemenang. Jumlah peserta dibatasi menjadi 20 peserta mengingat pandemi COVID-19 yang sedang melanda di berbagai daerah termasuk di KLU.

Sementara itu, beberapa tahapan yang dilakukan dalam kegiatan pengabdian ini antara lain:

1. Survei Awal

Survei awal yang bertujuan untuk mencari informasi mengenai panganan lokal yang menjadi produk unggulan di Desa Pemenang. Selain itu, dilakukan pula koordinasi dengan pemerintah desa dengan tujuan untuk mendapatkan rekomendasi lokasi pelaksanaan kegiatan. Pada tahap ini, dilakukan juga perekrutan peserta kegiatan sesuai dengan target peserta yang telah ditetapkan tim pelaksana kegiatan.

2. Tahap Persiapan

Pada tahap ini dilakukan persiapan alat dan bahan yang digunakan selama kegiatan pengabdian berlangsung. Selain itu, disiapkan pula materi yang akan disampaikan yaitu prosedur pembuatan bubuk kaldu dari cangkang dan kepala udang. Prosedur ini telah dicoba terlebih dahulu oleh tim pelatih sebelum kegiatan pengabdian dilaksanakan.

3. Tahap Pelakanaan

Pada tahap ini, pelatihan dimulai dengan menjelaskan secara umum mengenai latar belakang kegiatan pengabdian ini. Selanjutnya diberikan materi-materi sebagai berikut:

a. Kandungan nutrisi cangkang dan kepala udang

b. Proses pengolahan cangkang dan kepala udang menjadi bubuk kaldu

c. Pemanfaatkan kaldu cangkang dan kepala udang dalam panganan lokal untuk menambah cita rasa dan nilai ekonomi.

\section{HASIL DAN PEMBAHASAN}

Desa Pemenang, KLU dipilih sebagai lokasi kegiatan karena Desa ini merupakan salah satu desa yang sangat merasakan dampak dari bencana alam berupa gempa bumi di tahun 2018 hingga tahun 2021 dan juga adanya pandemi Covid19. 


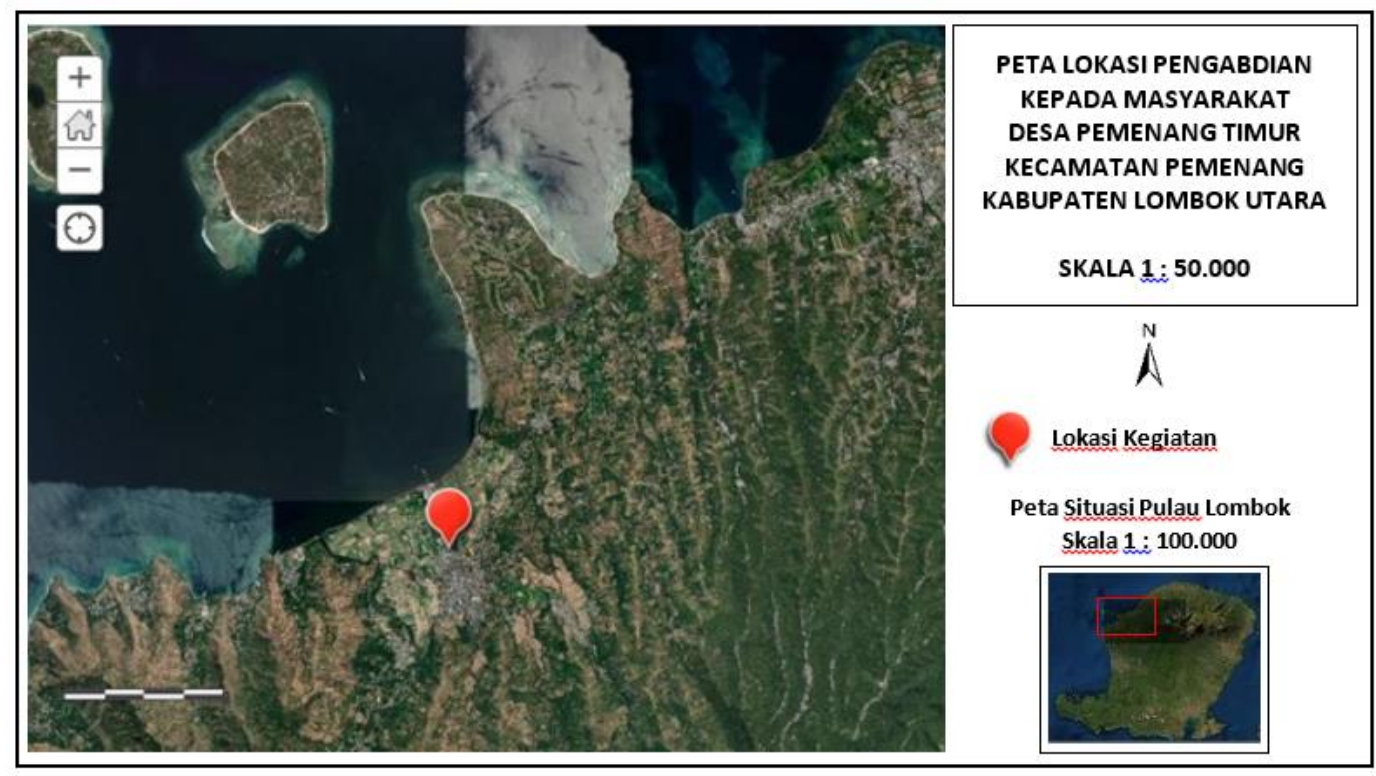

Gambar 1. Peta Lokasi Kegiatan

Salah satu sektor yang paling dipengaruhi oleh peristiwa-peristiwa tersebut adalah sektor pariwisata yang berimbas pada melemahnya perekonomian masyarakat. Dalam kegiatan PKM ini, hasil dari setiap tahapan yang ditelah dilaksanakan diuraikan sebagai berikut:

a. Survey awal

Berdasarkan hasil survey lapangan, diketahui bahwa salah satu panganan lokal yang berpotensi untuk dikembangkan dengan memanfaatkan bubuk kaldu dari limbah cangkang dan kepala udang ini adalah opak-opak. Opak-opak merupakan panganan sejenis kerupuk yang berbahan dasar sagu ubi dan kelapa. Panganan ini menjadi salah satu makanan yang sangat digemari masyarakat dari berbagai kalangan dan harganya murah. Dengan penambahan kaldu bubuk yang dibuat dalam kegiatan PKM ini, maka diharapkan kandungan nutrisi dan harga jual dari opak-opak dapat ditingkatkan.

Dari hasil survey awal inilah kemudian tim pelaksana menentukan peserta kegiatan yang merupakan ibu-ibu rumah tangga pembuat opak-opak. Dengan dipilihnya kelompok peserta tersebut, diharapkan panganan yang mereka kreasikan dengan bubuk kaldu udang ini akan mampu meningkatkan pendapatan para peserta kegiatan karena meningkatnya added value dari produk yang mereka buat. Selain itu, inovasi ini dapat membantu pemenuhan kebutuhan gizi masyarakat melalui konsumsi panganan yang mengandung protein.

\section{b. Persiapan Kegiatan PKM}

Adapun persiapan kegiatan yang dilakukan antara lain koordinasi dengan aparat desa setempat untuk mendapatkan izin kegiatan, menyiapkan alat dan bahan yang digunakan saat pelaksanaan kegiatan, menyiapkan materi kegiatan yang akan disampaikan kepada peserta kegiatan dan membuat sampel bubuk kaldu yang akan dibawa saat pelatihan.

Hasil dari tahapan ini yaitu tim pelaksana mendapatkan dukungan dari kepala desa. Tim pelaksana juga memperoleh rekomendasi calon-calon peserta yang berpotensi untuk diikutsertakan dalam kegiatan pengabdian. Peserta kegiatan yang direkrut yaitu ibu-ibu rumah tangga usia produktif dengan pekerjaan sampingan sebagai pembuat opak-opak.

Pada tahap ini, dilakukan pula penentuan jumlah peserta kegiatan. Mengingat pandemic COVID19 yang sedang melanda, termasuk di Desa Pemenang, maka, jumlah peserta kegiatan dibatasi 
menjadi 20 orang. Terkait dengan materi kegiatan, tim pelaksana menyiapkan materi mengenai kandungan nutrisi cangkang dan kepala udang dan manfaatnya bagi kesehatan. Selain itu, disiapkan pula materi mengenai proses pengolahan cangkang dan kepala udang hingga menjadi kaldu bubuk yang dapat dimanfaatkan.

\section{c. Pelaksanaan Program PKM}

Berdasarkan latar belakang sosial yaitu pendidikan dan ekonomi, diketahui bahwa hampir seluruh peserta kegiatan memiliki pendidikan terakhir yaitu sekolah dasar. Sementara itu, hampir seluruh peserta kegiatan berasal dari keluarga dengan perekonomian menengah ke bawah. Oleh karena itu, kegiatan pengabdian ini dirasakan sangat bermanfaat bagi para peserta sendiri. Selain karena informasi yang mereka peroleh, mereka juga memperoleh bantuan peralatan yang dapat digunakan untuk mengolah limbah cangkang dan kepala udang menjadi kaldu bubuk udang.

Pelaksanaan kegiatan PKM ini telah memberikan tambahan wawasan dan keterampilan tambahan kepada para peserta kegiatan. Beberapa di antaranya yaitu,

1. Peserta mengerti manfaat dari cangkang dan kepala udang sebagai bahan makanan

2. Peserta mengetahui pentingnya pemenuhan nutrisi dalam bahan makanan untuk menunjang pertumbuhan anak-anak dan kesehatan masyarakat

3. Peserta mengetahui cara mengolah cangkang dan kepala udang dengan benar sehingga menghasilkan bubuk kaldu bubuk cangkang dan kepala udang.

4. Peserta mengetahui manfaat kaldu bubuk udang sebagai zat aditif dalam panganan opak-opak yang akan mereka buat.

Adapun tahapan-tahapan yang dilakukan dalam pengolahan limbah cangkang dan kepala udang saat pelaksanaan kegiatan adalah sebagai berikut:

1. Udang dibersihkan dan dipisahkan antara kepala, cangkang dan daging udang.

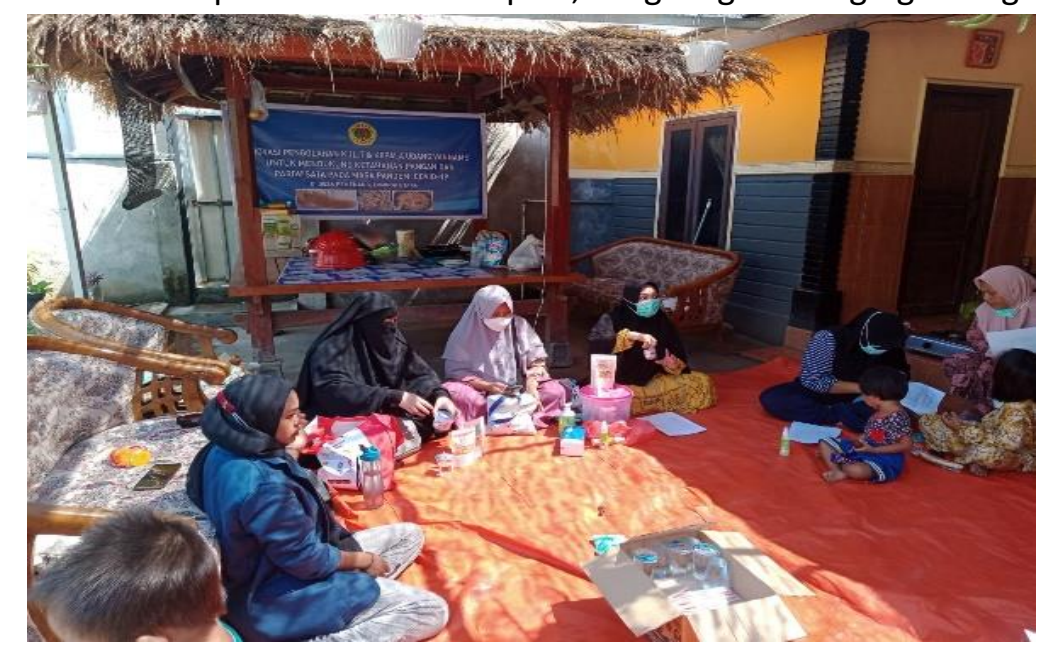

Gambar 2. Penyampaian Materi Kegiatan 


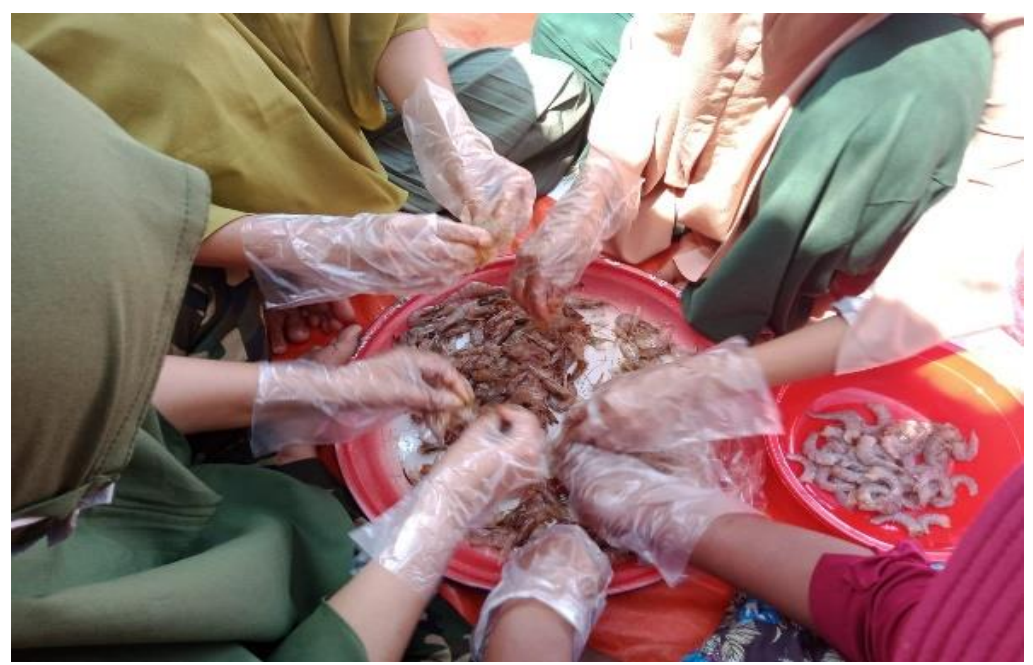

Gambar 3. Kegiatan Membersihkan dan Memisahkan Daging Udang dari Cangkang dan Kepala udang

2. Kepala dan cangkang udang yang telah dibersihkan selanjutnya disangrai hingga kering

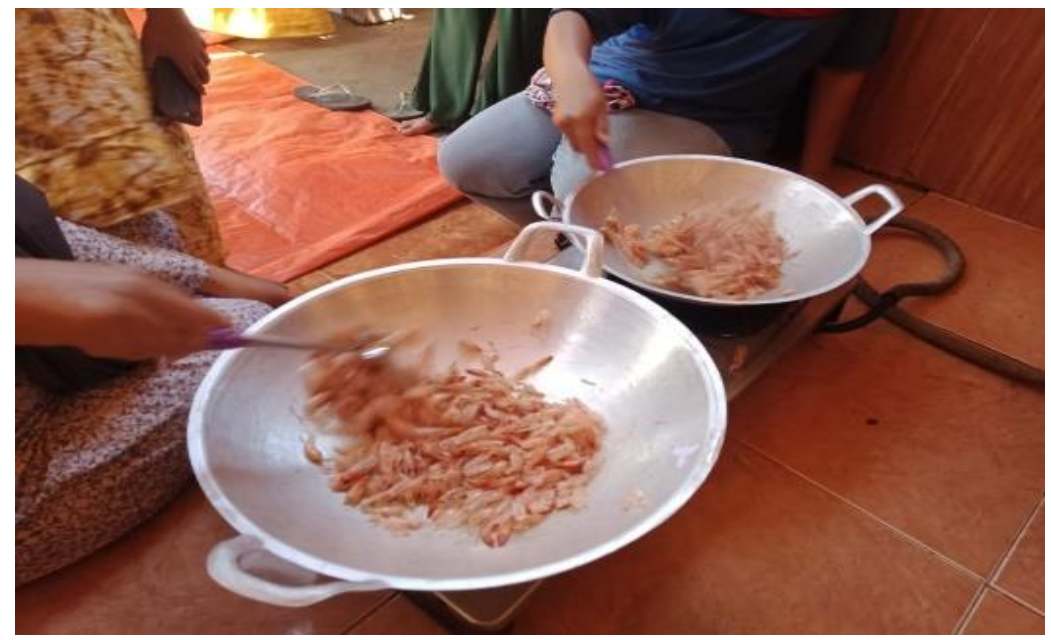

Gambar 4. Menyangrai Kepala dan Cangkang Udang

3. Kepala dan cangkang udang yang telah disangrai beserta bumbu dapur seperti garam, merica, dan bawang putih dihaluskan mengunakan blender. Sebelumnya, dilakukan penimbangan bahan-bahan yang akan dihaluskan sesuai dengan resep yang telah diberikan dalam salah satu materi kegiatan pengabdian. 


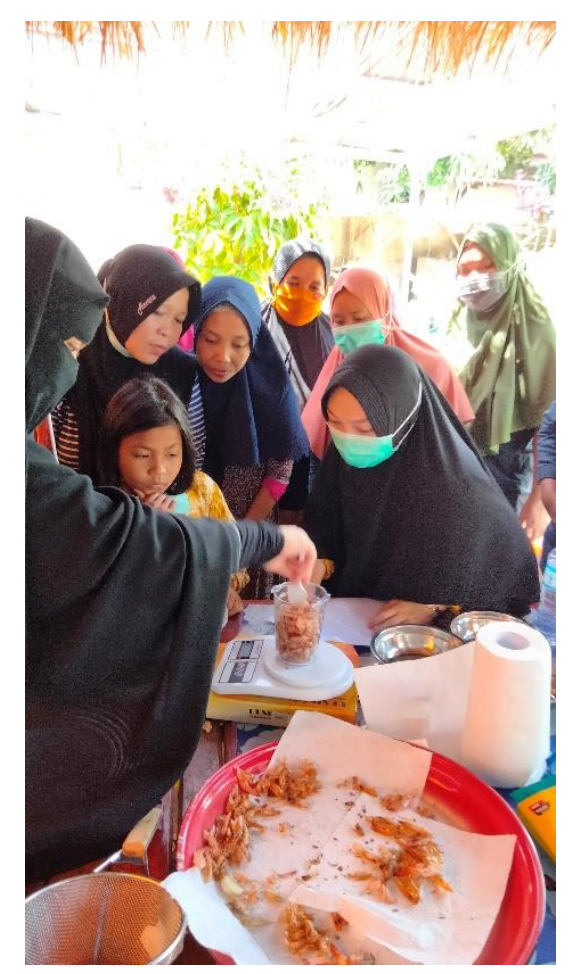

Gambar 5. Penimbangan Bahan-bahan yang Akan Dihaluskan

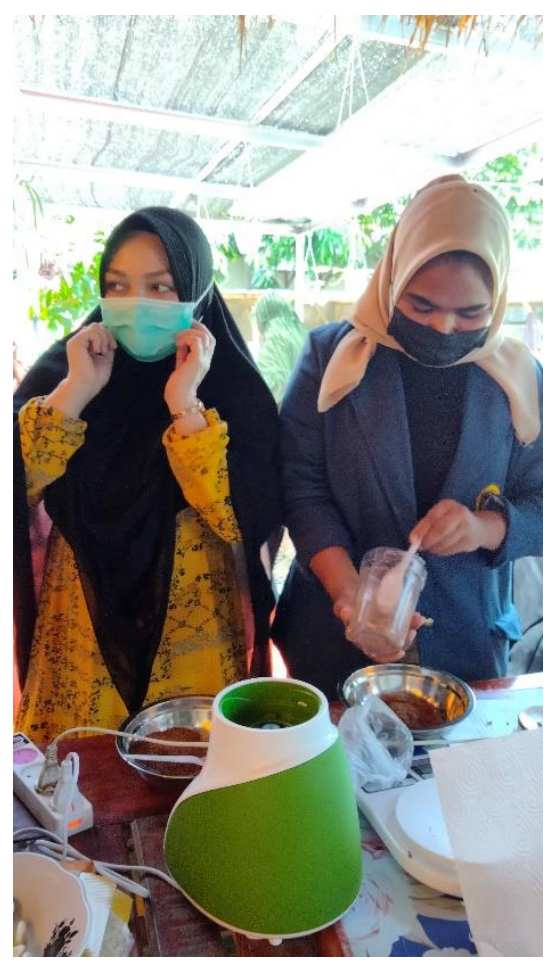

Gambar 6. Menghaluskan Bahanbahan yang Telah Ditimbang

4. Bahan-bahan yang telah dihaluskan disangrai kembali untuk mengurangi kandungan air dari bubuk kaldu.

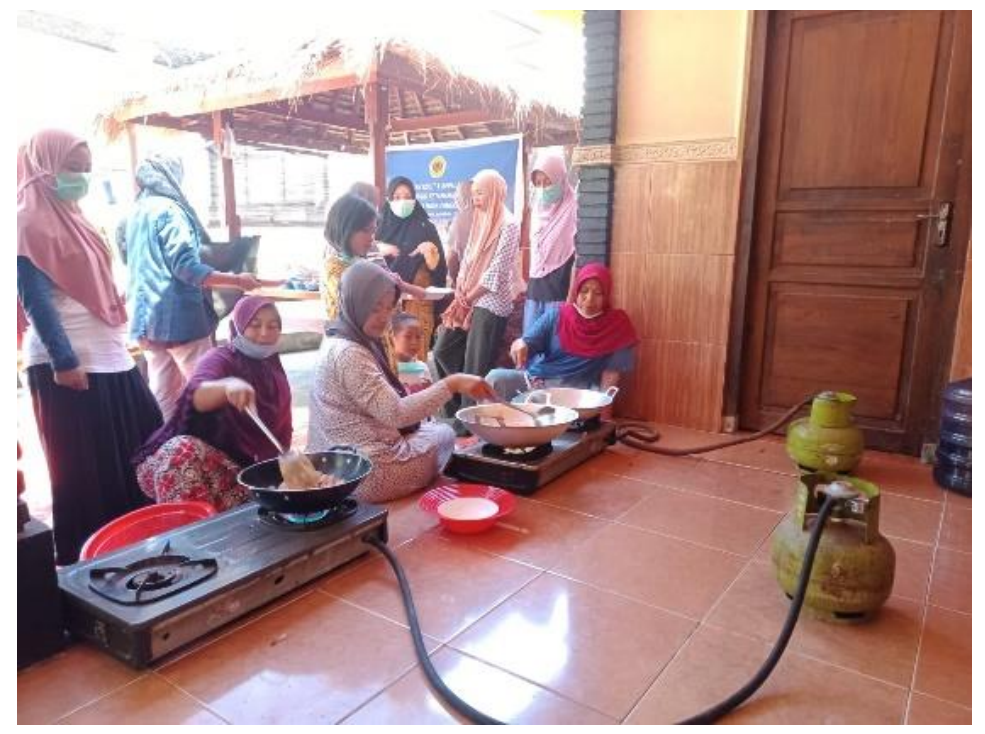

Gambar 7. Menyangrai Kembali Bahan-bahan yang Telah di Haluskan

5. Bahan-bahan yang telah disangrai ulang selanjutnya diblender kembali agar bubuk kaldu yang dihasilkan memiliki tekstur yang lebih halus lagi.

6. Bubuk kaldu yang telah halus dan kering siap ditambahkan ke bahan makanan lain sebagai zat aditif yang memiliki nilai gizi.

Sebagai tindak lanjut dari kegiatan pengabdian ini, bubuk kaldu yang telah dibuat oleh peserta kegiatan selanjutnya dianalisis di laboratorium untuk mengetahui kandungan nutrisinya. Berdasarkan 
hasil uji proksimat yang dilakukan, diketahui bahwa kandungan protein kasar yang terdapat pada bubuk kaldu tersebut yaitu 48,01\%, kandungan karbohidrat 4,17\%, serta kandungan lemak 20,95\%. Hal ini menunjukkan bahwa sebagai zat aditif untuk bahan makanan, bubuk kaldu cangkang dan kepala udang ini memiliki kandungan nutrisi yang cukup baik.

Selain melakukan uji terhadap kandungan protein, karbohidrat serta lemak, dilakukan pula uji IC-50 untuk mengetahui aktivitas antioksidan dari bubuk kaldu tersebut. Berdasarkan hasil analisis yang dilakukan, diketahui bahwa bubuk kaldu memiliki nlai IC-50 sebesar $11,77 \mathrm{mg} / \mathrm{mL}$, dengan kata lain, aktivitas antioksidannya lemah (Phongpaichit, 2007). Walaupun demikian, pengolahan kepala dan cangkang udang sebagai bubuk kaldu sekaligus menjadi zat aditif dapat menjadi solusi untuk pemanfaatan limbah rumah tangga yang memiliki nilai gizi.

Berdasarkan studi literatur, bubuk kaldu kepala dan cangkang udang memiliki aktivitas antioksidan yang baik. Oleh Karena itu, diperlukan penelitian lebih lanjut untuk mengetahui faktor penyebab rendahnya aktivitas antioksidan yang dimiliki oleh bubuk kaldu yang dihasilkan dari kegiatan pengabdian ini.

\section{KESIMPULAN DAN SARAN}

Berdasarkan hasil kegiatan ini, dapat disimpulkan bahwa, kegiatan pelatihan yang diberikan memberikan manfaat bagi peserta kegiatan berupa tambahan pengetahuan dan keterampilan dalam pengolahan limbah cangkang dan kepala udang. Sementara itu, diperlukan penelitian lebih lanjut mengenai proses pengolahan limbah cangkang dan kepala udang agar memperoleh bubuk kaldu dengan aktivitas antioksidan yang kuat.

\section{UCAPAN TERIMAKASIH}

Tim pelaksana kegiatan Pengabdian Kepada Masyarakat (PKM) menyampaikan terima kasih kepada Universitas Mataram atas bantuan dana yang diberikan untuk pelaksanaan kegiatan ini, serta kepada aparat Desa Pemenang Timur atas dukungan dan kerjasama yang baik dalam pelaksaan kegiatan ini.

\section{DAFTAR PUSTAKA}

Akbar, Z., Riyadi, S. \& Jaya, F. M. 2017. Pemanfaatan Kaldu Kepala Udang Vannamei (Litopenaeus vannamei) sebagai Flavor dalam Pengolahan Kerupuk Kemplang Ikan Lele Dumbo (Clarias gariepinus). Jurnal Ilmu-ilmu Perikanan dan Budidaya Perairan. Vol 12 (1), hal 27-33.

Atika, S. \& Handayani, L. 2019. Pembuatan Bubuk Flavour Kepala Udang Vannamei (Litopenaeus vannamei) sebagai Pengganti MSG (Monosodium Glutamat). Prosiding SEMDI-UNAYA (Seminar Nasional Multi Disiplin IImu UNAYA), Vol 3 (1), hal 18-26.

Farida, B. 2020. Budidaya Udang Vaname Sejahteraan Perempuan Pesisir di Lombok Utara. Lombok Post, https://lombokpost.jawapos.com/ekonomi-bisnis/14/10/2020/budidaya-udang-vanamesejahterakan-perempuan-pesisir-di-lombok-utara/

Nursyamsyi, M. 2018. Pariwisata Gili Sumbang 45\% PAD Lombok Utara. Republika.co.id, https://nasional.republika.co.id/berita/nasional/daerah/18/06/11/pa5nf6370-pariwisata-gilisumbang-45-persen-pad-lombok-utara

Phongpaichit, J. Nikom, N. Rungjindamai, J. Sakayaroj, N. Hutadilok-Towatana, V. Rukachaisirikul and K. Kirtikara. 2007. FEMS Immunol. Med. Microbiol. Vol 51 (3), hal 517-525.

Wowor, A. R. Y. 2015. Kandungan Protein Kasar, Kalsium dan Fosfor Tepung Limbah Udang sebagai Bahan Pakan yang diolah dengan Bahan Asetat $\left(\mathrm{CH}_{3} \mathrm{COOH}\right)$. Jurnal Zootek. Vol 35 (1), hal 1-9. 